Japan. J. Med. Sci. Biol., 31, 1-15, 1978

\title{
EXPERIMENTAL BOTULISM IN CHICKENS: THE CECUM AS THE SITE OF PRODUCTION AND ABSORPTION OF BOTULINUM TOXIN
}

\author{
Shuichi MIYAZAKI and GenjI SAKAGUCHI \\ College of Agriculture, University of Osaka Prefecture, Sakai-shi, Osaka 591, Japan
}

(Received: September 2, 1977)

\begin{abstract}
SUMMARY: Highly purified preparations of Clostridium botulinum toxins were administered to chickens by various routes. Chickens were highly susceptible to type A toxin, but relatively resistant to toxins of other types. Type C toxin (12S) at a dose of $1 \times 10^{7}$ mouse ip ${ } D_{50}$ failed to kill the chicken by the oral route. Oral administration of 10 or more of type A, C, or D spores killed normal chickens, whereas cecoligated chickens were insusceptible to oral administration of $10^{8}$ spores. These results show that the site of production and absorption of botulinum toxin in chickens is the cecum.

Peroral administration of spores of a type $\mathrm{C}$ strain cured of its prophages and producing the $\mathbf{C} 2$ factor only also killed normal chickens. Chickens appeared to be more susceptible to the $\mathrm{C} 2$ factor than to the $\mathrm{Cl}$ toxin. The $\mathrm{C} 2$ factor, therefore, may play more important role in chicken deaths from toxico-infection with type $\mathbf{C}$ organisms.

The optimum temperature for growth of $C$. botulinum types $\mathrm{C}$ and $\mathrm{D}$ was found to be $40-42 \mathrm{C}$. Type $\mathrm{C}$ and $\mathrm{D}$ toxins were significantly more stable than type $\mathrm{A}$ toxin in the cecum contents with $\mathrm{pH}$ above 7 . These characteristics and the high density of distribution of type $C$ spores in the environment may explain prevailing cases of type $\mathbf{C}$ botulism among broiler chickens.
\end{abstract}

\section{INTRODUCTION}

Botulism affects both man and animals. It is regarded as being caused generally by ingestion of preformed toxin. The main site of toxin absorption is considered to be the duodenum in mammals (Dack and Gibbard, 1926; Dack and Hoskins, 1942; Dack and Wood, 1927; May and Whaler, 1958; Sugii, Ohishi and Sakaguchi, 1977).

Most cases of human botulism have been caused by type $\mathrm{A}, \mathrm{B}$, and $\mathrm{E}$ toxins and those of animal botulism by type $\mathrm{C}$ and $\mathrm{D}$ toxins. Cases of avian botulism, particularly of wild ducks and broiler chickens (Blanford and Roberts, 1970; Roberts and Collings, 1973; Roberts, Thomas and Gilbert, 1973; Page and Flettcher, 1974; Haagsma, 1974) have been caused by type $\mathbf{C}$ toxin.

It was demonstrated that chickens are highly susceptible to type $\mathbf{C}$ toxin by the oral route, but they are 1,000 times more susceptible to type A toxin

宮崎修一・阪口玄二（大阪府立大学農学部 獣医公衆衛生学教室 堺市百舌鳥梅町 4 丁 804) 
than to type $\mathrm{C}$ toxin when administered intravenously (Gross and Smith, 1971). A higher rate of intestinal absorption of type $\mathrm{G}$ toxin than type $\mathrm{A}$ toxin in the chicken was suggested.

In an outbreak of type $\mathrm{C}$ botulism among broiler chickens, no source of preformed toxin was found, but type $\mathbf{C}$ organisms were detected in the feed, litter and other specimens (Roberts et al., 1973). Outbreaks of type C botulism among broiler chickens have been reported from England (Roberts and Collings, 1973; Smart and Roberts, 1977), the United States (Page and Flettcher, 1974), and the Netherlands (Haagsma, 1974). In the most recent outbreak, Smart and Roberts (1977) detected several thousand type C organisms per gram of the litter and the intestinal contents of the chickens. These reports suggest that broiler chickens ingest type $\mathrm{C}$ spores rather than preformed toxin. The ingested spores would germinate, grow and produce toxin somewhere in the alimentary tract of the chicken (Roberts et al., 1973; Smart and Roberts, 1977). The exact site of production and absorption of the toxin in the alimentary tract of the chicken has not been elucidated.

C. botulinum type $\mathrm{C}$ and $\mathrm{D}$ resemble each other biologically and both produce multiple toxic factors. According to Jansen (1971), type $\mathrm{C} \alpha$ organisms produce three toxic factors, C1, C2, and D; type $\mathrm{C} \beta$ organisms a single factor, C2; and type D organisms two factors, $\mathrm{Cl}$ and $\mathrm{D}$. Of these toxic factors, the C2 factor only can be activated with trypsin (Jansen and Knoetze, 1971; Eklund and Poysky, 1972). The role played by the C2 factor in chicken botulism is obscure.

The present investigation was undertaken to answer the following questions concerning possible toxico-infection of broiler chickens with $C$. botulinum type C: (1) susceptibilities of the broiler chicken to purified toxins of different types not containing multiple toxic factors, (2) the site of in vivo toxin production, (3) the site of absorption of the toxin, (4) the role of the C2 factor in chicken botulism, and (5) the connection between broiler chickens and C. botulinum type C.

\section{Materials ANd Methods}

C. botulinum toxins: Toxins produced by $C$. botulinum type A strain Hall, type B strain Okra, type C strain CB19 (Itoh et al., 1976), type D strain CB16 (Miyazaki, Iwasaki and Sakaguchi, 1977), type E strain German sprats, and type $\mathrm{F}$ strain Langeland in a peptone-yeast extract-glucose (PYG) medium were purified by the methods reported previously (Kitamura, Sakaguchi and Sakaguchi, 1968; Kozaki, Sakaguchi and Sakaguchi, 1974; Ohishi and Sakaguchi, 1974; Sugii and Sakaguchi, 1975; Miyazaki et al., 1977). Type C toxin was highly purified by the methods originally described for purifying type D toxin. Differently molecular-sized toxins were obtained except for type $\mathbf{E}$ and $\mathrm{F}$ toxins. In this report, "toxin" denotes $12 S$ progenitor toxin (M toxin). Other toxins will be specified when necessary. Neutralization tests proved that neither the 
type $\mathrm{C}$ nor the type $\mathrm{D}$ toxin preparation contained the $\mathrm{C} 2$ factor.

The C2 factor was obtained from cultures of a UV-cured type C strain C203-U28NT (Oguma, Iida and Inoue, 1973), producing no Cl toxin but only trypsin-activable toxin, given by Dr. H. Iida, Department of Microbiology, Hokkaido University School of Medicine, Sapporo. The strain was grown in PYG medium fortified with $1.0 \%$ Cooked meat medium (Difco) for 3 days at $37 \mathrm{C}$. The C2 factor, at a potential toxicity of about $100 \mathrm{MLD} / \mathrm{ml}$, was precipitated with ammonium sulfate at $60 \%$ saturation at $\mathrm{pH} 4.0$, extracted with $0.05 \mathrm{M}$ acetate buffer, $\mathrm{pH} 6.5$, containing $1 \mathrm{M} \mathrm{NaCl}$, and concentrated by ultrafiltration through Amicon PM30 membrane (Amicon, Lexington, MA). The C2 factor was identified by neutralization with anti-C2 factor serum given by Dr. M. W. Eklund, Pacific Utilization Research Center, National Marine Fisheries Service, Seattle, WA.

Crystalline type A toxin (19S) was given by Dr. E. J. Schantz, Food Research Institute, University of Wisconsin, Madison, WI. The $7 \mathrm{~S}$ derivative toxins of types $\mathbf{A}$ and $\mathbf{D}$ were obtained from the respective toxin by DEAESephadex chromatography at pH 8 (Kitamura, Sakaguchi and Sakaguchi, 1969).

All activable toxins, namely type B (Kozaki et al., 1974), E (Kitamura et al., 1968), and D (Miyazaki et al., 1977) toxins, and C2 factor (Jansen and Knoetze, 1971; Eklund and Poysky, 1972) were treated with trypsin at $0.2 \mathrm{mg} / \mathrm{ml}$ for 30 min at $\mathrm{pH} 6.0$ and $35 \mathrm{C}$ before administration. The toxicities were determined by the time-to-death method by iv injection of $0.1-\mathrm{ml}$ doses into mice and expressed in equivalent ip $\mathrm{LD}_{50}$ (Boroff and Fleck, 1966).

C. botulinum spores: Type A spores of strain 62A were prepared by the method reported by Schmidt and Nank (1960). Type C (strains CB19 and C203-U28NT) and D (strain 1873) spores were prepared in the biphasic system (Bruch, Bohrer and Denny, 1968) using an agar phase consisting of Cooked meat medium (Difco) fortified with $0.4 \%$ glucose, $1 \%$ yeast extract, $1 \%$ ammonium sulfate (Segner, Schmidt and Boltz, 1971), and 0.1\% L-cysteine hydrochloride.

The spore suspensions in distilled water were heated for $15 \mathrm{~min}$ at $80 \mathrm{C}$ (at $60 \mathrm{C}$ for type E) and kept frozen until used. Viable counts were made by colony counting in Brain heart infusion agar (BBL) fortified with filter-sterilized $0.1 \%$ L-cysteine hydrochloride and $0.01 \%$ dithiothreitol (Moore, 1968) in anerobic pouches (Greenberg, Bladel and Zingelmann, 1966) by incubation for 2 days at $37 \mathrm{C}$.

Chickens: One-day-old male chickens, White Leghorn Hy-Line, were purchased from a commercial hatchery and reared for 2 weeks in an electrically heated battery of brooders (Ohmiya Manufacturing Co., Kyoto) by feeding commercial feed containing no antibiotics.

Cecoligation: The chicken at 7 days of age was subjected to midventral laparotomy under anesthesia. The duodenum was drawn out and covered with a piece of saline-moistened cotton. The necks of both parts of the cecum were tied together with thread at two places. The duodenum was replaced and the abdominal incision was sutured. The cecoligated chickens were reared for an 
additional week and used for spore administration.

Administration of toxin to chickens: Intravenous injection was made into v. cutaneaulnaris at a $0.1-\mathrm{ml}$ dose. Oral administration was made into the crop with a metal catheter at a $0.5-\mathrm{ml}$ dose. Intraduodenal injection with a $0.1-\mathrm{ml}$ sample was made immediately after the necks of the both parts of the cecum had been tied off to prevent toxin from entering the cecum. After intraduodenal injection, the abdominal incision was sutured.

For intracecal injection, the chicken at 2 weeks of age was anesthetized and laparotomized. A threaded needle was passed under the cecum to tie the two necks loosely at two places. Through the knots, a $0.1-\mathrm{ml}$ sample was injected into one part of the cecum. No sooner than the hypodermic needle was withdrawn, the knots were tightened as quickly as possible to prevent the inoculum from leaking out. The abdominal incision was sutured.

All the chickens were observed for 7 days after administration of toxin.

Administration of spores: A $0.5-\mathrm{ml}$ portion of suspensions of various concentrations of type A, C or D spores was administered into the crop with a metal catheter. Both normal and cecoligated chickens were used at 14 days of age. The chickens were kept at 20-24 C and observed for 3 weeks.

Determination of toxin: When chickens died, they were autopsied. Blood serum which had been separated in the heart was taken. Contents of the crop, proventiculus and gizzard, upper intestine, lower intestine, and the cecum were taken and weighed, and each was suspended in $10 \mathrm{ml}$ of sterile saline. A 2-g sample of the liver was taken, cut up into fine pieces, and suspended similarly in $10-\mathrm{ml}$ saline. Each suspension was diluted 10-fold serially in saline. A $0.5-\mathrm{ml}$ portion each of serial dilutions was inoculated intraperitoneally into a mouse to determine a rough minimum lethal dose (MLD).

When the mouse died, the toxin was identified by the neutralization test in mice protected with monovalent antitoxins (0.25 IU of anti-type A and antitype C, 2.5 IU of anti-type D, and a quantity of anti-C2 factor neutralizing about $500 \mathrm{MLD}$ of the $\mathrm{C} 2$ factor). Antitoxins types $\mathrm{A}, \mathrm{C}$, and $\mathrm{D}$ were given by Dr. H. Kondo, Chiba Serum Institute, Ichikawa, Chiba, Japan and anti-C2 factor by Dr. M. W. Eklund, U.S.A.

Detection of C. botulinum: The suspensions of the liver and of the contents of different parts of the alimentary tract were each inoculated into a tube of cooked liver medium, which was incubated for 3 days at $37 \mathrm{C}$. The culture supernatant was injected intraperitoneally into a mouse. When the mouse died and the culture was neutralized by only the corresponding type of the monovalent antitoxins, the sample was regarded as containing the organisms.

Other methods: Protein contents of purified toxin preparations were determined according to Lowry et al. (1951).

The antigenicity of the toxin in blood was determined by the reversed passive hemagglutination (RPHA) using sheep erythrocytes coupled with antitoxic globulins type $\mathrm{A}$ and $\mathrm{C}$ separated by affinity chromatography (Sakaguchi et al., 1974). The minimum detectable quantity of type A toxin was $20 \mathrm{ng}$ and 
type $\mathrm{C}$ toxin $30 \mathrm{ng}$ per well in the microtiter tray.

Optimum temperature for growth was determined in a temperature-gradient incubator with a water bath holding 23 liters of water (Toyo Kagaku Sangyo, Tokyo). The medium used was the same as that used for viable counting of spores. Spores of each of type A (final concentration 400 viable spores $/ \mathrm{ml}$ ), type $\mathrm{C}(2,000 / \mathrm{ml})$, type $\mathrm{D}(9,000 / \mathrm{ml})$, and type $\mathrm{E}(3,500 / \mathrm{ml})$ were mixed with the melted agar at $48 \mathrm{C}$. The agar-spore mixture $(2.1 \mathrm{ml})$ was sucked into a sterile glass tubing $(5 \times 300 \mathrm{~mm})$ with a cotton plug at one end. The bottom end was sealed with putty. The tubings were incubated in a vertical position in the water bath with temperature gradient from 15 to $62 \mathrm{C}$ for $24 \mathrm{hr}$, during which period the tubings were observed occasionally for the development of colony zones through the window glass of the water bath. The height of the colony zone developed was measured and converted to temperature from the height-temperature curve calibrated previously.

Intestinal fluid was collected from the duodenum of five chickens. Cecal contents of five chickens were washed out with $5 \mathrm{ml}$ of distilled water. Intestinal fluid and suspensions of cecal contents were kept standing overnight under refrigeration. The supernatants were taken.

\section{RESUlTS}

\section{Administration of Botulinum Toxins by Various Routes}

Toxins of different types were each administered to 2-week-old chickens intravenously, perorally, intraduodenally, and intracecally to determine MLD (Table I).

\section{TABLE I}

Chicken minimum lethal doses $(M L D)^{1}$ of botulinum toxins of different types administered by different routes

\begin{tabular}{lcccc}
\hline \multirow{2}{*}{ Toxin } & \multicolumn{4}{c}{ Chicken MLD in mouse ip LD $_{50}$} \\
\cline { 2 - 5 } & Intravenous & Peroral & Intraduodenal & Intracecal \\
\hline A-cryst. & $\mathrm{ND}^{2}$ & $10^{5}$ & $10^{4}$ & $10^{2}$ \\
A-M & $10^{1}$ & $10^{7}$ & $10^{6}$ & $10^{2}$ \\
B-M & $10^{4}$ & ND & ND & ND \\
C-M & $10^{4}$ & $>10^{7}$ & $10^{6}$ & $10^{5}$ \\
C2 factor & $10^{1}$ & $>10^{4}$ & $>10^{4} 3$ & $10^{2}$ \\
D-M & $10^{6}$ & $>10^{7}$ & $>10^{73}$ & $10^{6}$ \\
E & $10^{4}$ & ND & ND & ND \\
F & $10^{6}$ & ND & ND & ND \\
\hline
\end{tabular}

1 One ckicken MLD was defined as a dose of the toxin killing three or more of a group of five chickens and expressed in number of mouse ip $\mathrm{LD}_{50}$.

2 Not done.

3 Two of five chickens died with the indicated doses. 
TABLE II

Toxicities of serum samples of chickens administered with toxins of different types by different routes

\begin{tabular}{|c|c|c|c|}
\hline Toxin & Route & Dose in mouse ip & $\begin{array}{l}\text { Toxicity of serum in } \\
\text { mouse ip MLD } / \mathrm{ml}\end{array}$ \\
\hline \multirow[t]{7}{*}{ A-cryst. } & Peroral & $10^{6}$ & 2 \\
\hline & & $10^{5}$ & -1 \\
\hline & & $10^{5}$ & - \\
\hline & Intraduodenal & $10^{5}$ & 2 \\
\hline & & $10^{4}$ & - \\
\hline & Intracecal & $10^{3}$ & - \\
\hline & & $10^{2}$ & - \\
\hline \multirow[t]{6}{*}{ A-M } & Peroral & $10^{7}$ & 2 \\
\hline & & $10^{7}$ & 2 \\
\hline & Intraduodenal & $10^{6}$ & 2 \\
\hline & Intracecal & $10^{6}$ & 2 \\
\hline & & $10^{4}$ & - \\
\hline & & $10^{2}$ & - \\
\hline \multirow[t]{4}{*}{$\mathrm{C}-\mathrm{M}$} & Intraduodenal & $10^{6}$ & $2 \times 10^{2}$ \\
\hline & & $10^{6}$ & $2 \times 10^{2}$ \\
\hline & Intracecal & $10^{6}$ & $2 \times 10^{2}$ \\
\hline & & $10^{5}$ & $2 \times 10^{1}$ \\
\hline \multirow[t]{4}{*}{ D-M } & Intraduodenal & $10^{7}$ & $2 \times 10^{2}$ \\
\hline & & $10^{7}$ & $2 \times 10^{2}$ \\
\hline & Intracecal & $10^{7}$ & $2 \times 10^{2}$ \\
\hline & & $10^{7}$ & $2 \times 10^{2}$ \\
\hline \multirow[t]{5}{*}{ C2 factor } & Intraduodenal & $10^{4}$ & - \\
\hline & Intracecal & $10^{3}$ & - \\
\hline & & $10^{3}$ & - \\
\hline & & $10^{2}$ & - \\
\hline & & $10^{2}$ & - \\
\hline
\end{tabular}

$1<2 \mathrm{MLD} / \mathrm{ml}$

Chicken iv MLD of type $\mathrm{C}$ toxin was $1 \times 10^{4}$ mouse ip $\mathrm{LD}_{50}$, being the same as those of type $\mathrm{B}$ and $\mathrm{E}$ toxins, one-hundredth those of type $\mathrm{D}$ and $\mathrm{F}$ toxins, and 1,000 times larger than that of type $\mathrm{A}$ toxin.

Chicken oral MLD of type A crystalline toxin was $1 \times 10^{5}$ mouse ip $\mathrm{LD}_{50}$ and that of type $A$ toxin $1 \times 10^{7}$ mouse ip $\mathrm{LD}_{50}$. Neither type $\mathrm{C}$ nor type $\mathrm{D}$ toxin, nor $\mathrm{L}$ toxin $(16 \mathrm{~S})$ of either type, in a dose of $1 \times 10^{7}$ mouse ip $\mathrm{LD}_{50}$ killed any chicken. MLD.

Chicken intraduodenal MLD of any toxin was about 0.1 quantity of oral

Chicken intracecal MLD of any toxin was the smallest in mouse ip $\mathrm{LD}_{50}$ of those determined by any route of administration. Type $\mathrm{C}$ and $\mathrm{D}$ toxins in doses corresponding to $1 \times 10^{5}$ and $1 \times 10^{7}$ mouse ip $\mathrm{LD}_{50}$, respectively, were lethal to the chicken.

It is noteworthy that the C2 factor was more toxic to the chicken than 
type $\mathbf{C}$ toxin at least by the iv, intraduodenal, and intracecal routes.

Table II shows the toxicities in mouse ip $\mathrm{MLD} / \mathrm{ml}$ of serum specimens taken from the hearts of dead chickens. The serum specimens taken from type A-toxin recipients contained 2 mouse ip $\mathrm{MLD} / \mathrm{ml}$ or lower toxicities regardless the route of toxin administration. The serum levels of type $\mathrm{C}$ and $\mathrm{D}$-toxin recipients were considerably higher than those of type A-toxin recipients. No toxicity was detected in the serum of the C2-factor recipients.

The changes with time in the blood levels of toxicity to mice and the RPHA titers of two chickens are shown in Fig. 1. One was given type A toxin $\left(0.1 \mathrm{mg}\right.$ or $8.0 \times 10^{6}$ mouse ip $\left.\mathrm{LD}_{50}\right)$ and the other type $\mathrm{C}$ toxin $(0.1 \mathrm{mg}$ or $1.0 \times 10^{6}$ mouse ip $\mathrm{LD}_{50}$ ) both intraduodenally. The blood level of toxicity of the type A-toxin recipient was very low, being 4 mouse ip $\mathrm{MLD} / \mathrm{ml} \mathrm{1,2}$ and $4 \mathrm{hr}$ after administration, but the RPHA titer was on the same level as that of the type C-toxin recipient, as RPHA with type A toxin was 1.5 times more sensitive than that with type $\mathrm{C}$ toxin as described in Materials and Methods. The blood level of toxicity of type C-toxin recipient was 4,000 mouse ip MLD/ml at $1 \mathrm{hr}$ and $400 \mathrm{MLD} / \mathrm{ml}$ at 2, 4 and $6 \mathrm{hr}$ after administration.

\section{Oral Administration of Spores to Normal Chickens}

All the chickens administered perorally with $10^{2}$ or more of type $\mathrm{A}, \mathrm{C}$, or $\mathrm{D}$ spores developed illness in 5 to 12 days and died in an additional day or two (Table III). Some but not all (1 to 3 of 5 ) chickens administered perorally with 10 spores of any of these types died. Neither the incubation period nor the course of illness seemed to be dependent upon the dose. None of the chickens administered perorally with $10^{3}$ spores of the cured type $\mathrm{G}$ strain died, but 3 of the chickens fed with $10^{4}$ spores died; one on the 5th and the other on the

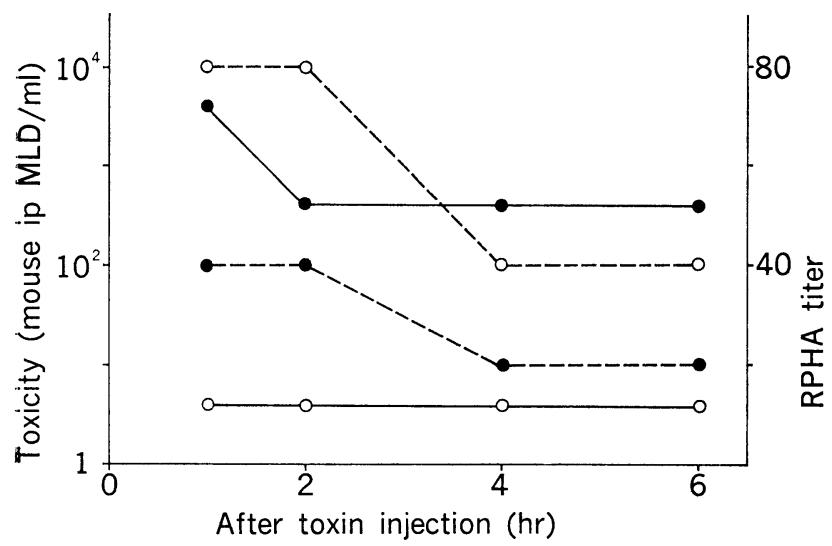

Fig. 1. Blood levels of toxicities and antigenicities of chickens administered intraduodenally with $0.1 \mathrm{mg}$ of type $\mathrm{A}$ or $\mathrm{C}$ toxin. Solid line represents toxicity in mouse ip $\mathrm{MLD} / \mathrm{ml}$ and dotted line RPHA titer. Symbols: $\bigcirc$, type A; $\bullet$, type C. 
TABLE III

Fatalities of normal chickens administered perorally with spores

\begin{tabular}{lcccccccccc}
\hline \multirow{2}{*}{ Type } & $\begin{array}{c}\text { Dose of } \\
\text { spores }\end{array}$ & 6 & 7 & 8 & 9 & 10 & 11 & 12 & 13 & \multicolumn{1}{c}{$\begin{array}{c}\text { Deaths/ } \\
\text { tested }\end{array}$} \\
\cline { 3 - 10 } & $10^{3}$ & & & & 2 & & 3 & & & $5 / 5$ \\
\hline A & $10^{2}$ & & & 1 & 3 & & 1 & & & $5 / 5$ \\
& $10^{1}$ & & & & & & & 1 & & $1 / 5$ \\
& $10^{3}$ & 1 & & & 1 & 1 & & & 2 & $5 / 5$ \\
C & $10^{2}$ & & & & 1 & 1 & & 2 & 1 & $5 / 5$ \\
& $10^{1}$ & & 2 & & 1 & & & & & $3 / 5$ \\
& $10^{3}$ & 1 & 1 & & & & 1 & 1 & 1 & $5 / 5$ \\
& $10^{2}$ & & 1 & & & & 2 & & 2 & $5 / 5$ \\
& $10^{1}$ & 1 & 1 & & & & & & & $2 / 5$ \\
& $10^{4}$ & & 1 & & & & & 2 & & $3 / 5$ \\
& $10^{3}$ & & & & & & & & & $0 / 5$ \\
\hline
\end{tabular}

TABLE IV

Distribution of toxin in the alimentary tract of chickens died after peroral administration with spores

\begin{tabular}{|c|c|c|c|c|c|c|}
\hline \multirow[b]{2}{*}{ Type } & \multirow{2}{*}{$\begin{array}{l}\text { Dose of } \\
\text { spores }\end{array}$} & \multicolumn{5}{|c|}{ Mouse ip MLD/g of contents } \\
\hline & & Crop & $\begin{array}{l}\text { Proventriculus } \\
\text { and gizzard }\end{array}$ & $\begin{array}{l}\text { Upper } \\
\text { intestine }\end{array}$ & $\begin{array}{l}\text { Lower } \\
\text { intestine }\end{array}$ & Cecum \\
\hline \multirow[t]{5}{*}{ A } & $10^{6}$ & - & - & - & - & 100 \\
\hline & $10^{5}$ & - & - & - & 3 & 80 \\
\hline & $10^{4}$ & - & - & - & - & 10 \\
\hline & $10^{3}$ & - & - & - & 3 & 70 \\
\hline & $10^{2}$ & - & 一 & - & - & 10 \\
\hline \multirow[t]{5}{*}{ C } & $10^{4}$ & - & - & - & 5 & 300 \\
\hline & $10^{4}$ & - & - & - & 3 & 800 \\
\hline & $10^{3}$ & - & - & - & 3 & 100 \\
\hline & $10^{2}$ & - & - & - & 7 & 200 \\
\hline & $10^{1}$ & - & - & - & 2 & 200 \\
\hline \multirow[t]{4}{*}{$\mathrm{D}$} & $10^{3}$ & - & - & - & 8 & 200 \\
\hline & $10^{3}$ & - & - & - & - & 70 \\
\hline & $10^{2}$ & - & - & - & 4 & 100 \\
\hline & $10^{1}$ & - & - & - & - & 200 \\
\hline \multirow[t]{2}{*}{ Cured C } & $10^{4}$ & - & - & - & - & 50 \\
\hline & $10^{4}$ & - & - & - & - & 40 \\
\hline
\end{tabular}

12th days after administration. The incubation period and symptoms were not significantly different from those fed with the toxigenic type $\mathrm{G}$ spores. There was a tendency that the chickens fed with type $\mathrm{C}, \mathrm{D}$ or cured type $\mathrm{C}$ spores died rather more quickly after the onset of illness than those fed with type $A$ spores.

The dead chickens were examined for the toxin distribution in the serum, 


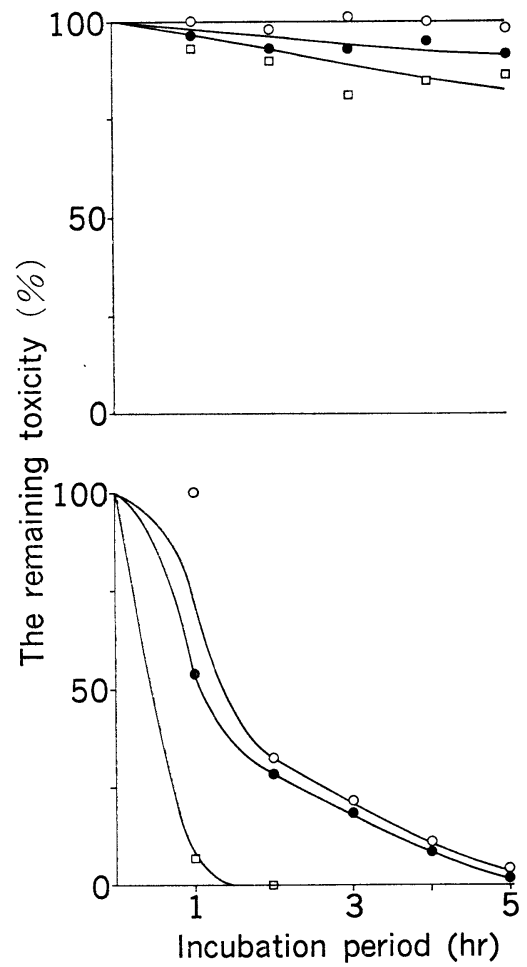

Fig. 2. Stabilities of type A, C and D toxins in duodenal and cecal fluids at 41 C. (Top) In duodenal fluid. (Bottom) In cecal fluid. Concentration of toxin: $10 \mu \mathrm{g} / \mathrm{ml}$. Initial toxicity: type A $8.0 \times 10^{5}$, type C $1.0 \times 10^{5}$, and type $\mathrm{D} 8.0 \times 10^{5}$ mouse ip $\mathrm{LD}_{50} / \mathrm{ml}$. Symbols: $\square-\square$, type A toxin; $O-O$, type $\mathrm{C}$ toxin; - -0 , type $\mathrm{D}$ toxin.

liver, and different parts of the alimentary tract. No toxin was detected in the serum, crop, proventriculus and gizzard, upper intestine, or liver of any chicken. The toxin was detected in the ceca of all and in the lower intestines of some chickens. The toxicity of the cecum contents was always higher than that of the contents of the lower intestine. The toxicity of the cecum contents of type C-spore recipients was 100-800 mouse ip MLD/g, that of type D-spore recipients 70-200 MLD/g, and that of type A-spore recipients 10-100 MLD/g (Table IV).

In cured type C-spore recipients, mouse lethal activity was detected only in the cecum at a titer of $40-50 \mathrm{MLD} / \mathrm{g}$.

C. botulinum organisms were demonstrated in all the specimens of the digestive tracts of all the chickens regardless of the presence or absence of toxin and in the liver of some chickens.

\section{Oral Administration of Spores to Cecoligated Chickens}

The foregoing experiments indicated that the main site of production and 


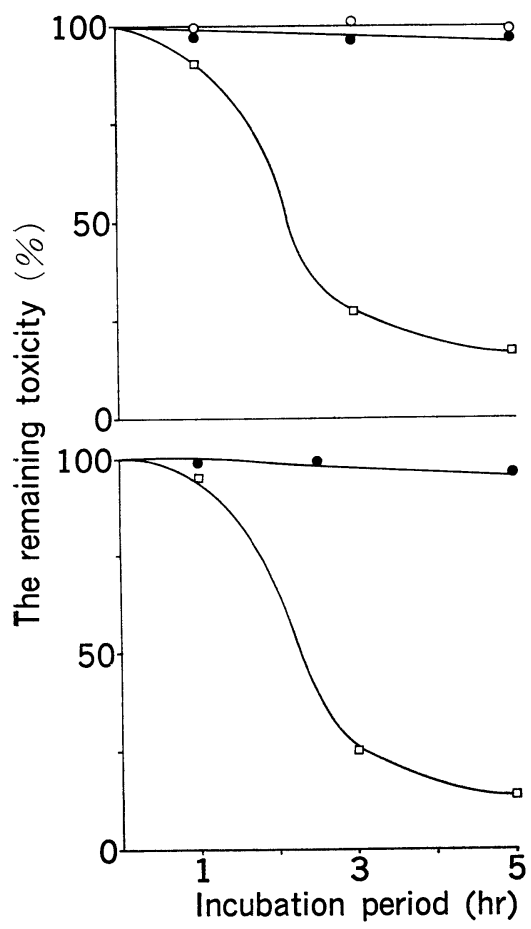

Fig. 3. Stabilities of type A, C and D toxins in $0.01 \mathrm{~m}$ phosphate buffer, $\mathrm{pH} 7.5$, at $41 \mathrm{C}$. (Top) $\mathrm{M}$ toxin (12S). Concentration of toxin: $10 \mu \mathrm{g} / \mathrm{ml}$. Initial toxity: type A $8.0 \times 10^{5}$, type C $1.0 \times 10^{5}$, and type $\mathrm{D} 8.0 \times 10^{5}$ mouse ip $\mathrm{LD}_{50} / \mathrm{ml}$. (Bottom) Derivative toxin $(7 \mathrm{~S}$ ). Concentration of derivative toxin: $5 \mu \mathrm{g} / \mathrm{ml}$. Initial toxicity: type $A 1.2 \times 10^{\circ}$ and type D $9.5 \times 10^{5}$ mouse ip $\mathrm{LD}_{50} / \mathrm{ml}$. Symbols: $\square \longrightarrow \square$, type $A$; $\bigcirc \longrightarrow \bigcirc$, type $C$; $\bigcirc-\bigcirc$, type D.

absorption of toxin was the cecum. To give additional evidence for this indication, peroral administration of spores was performed to cecoligated chickens. To each of 5 cecoligated chickens at 2 weeks of age, $1 \times 10^{6}$ spores of type $\mathrm{A}, \mathrm{C}$, D or cured type $\mathbf{C}$ strain were administered perorally. All but one, which was given type A spores, survived for 3 weeks without any sign of illness. The one which died on the 8th day was autopsied. One part of the cecum was diminutive in size but the other part had developed into a normal size, harboring type A toxin and organisms in it.

\section{In Vitro Stabilities of Type A, C, and D Toxins in Intestinal and Cecal Fluids}

When botulinum toxin $(10 \mu \mathrm{g} / \mathrm{ml})$ was incubated in intestinal fluid, $\mathrm{pH} 6.2$, at $41 \mathrm{C}$, the rate of inactivation was rather low and no significant differences in the rate of inactivation were found among type $\mathrm{A}, \mathrm{C}$, and $\mathrm{D}$ toxins (Fig. 2, top). On the other hand, when toxin was incubated in cecal fluid, $\mathrm{pH} 7.4$, 


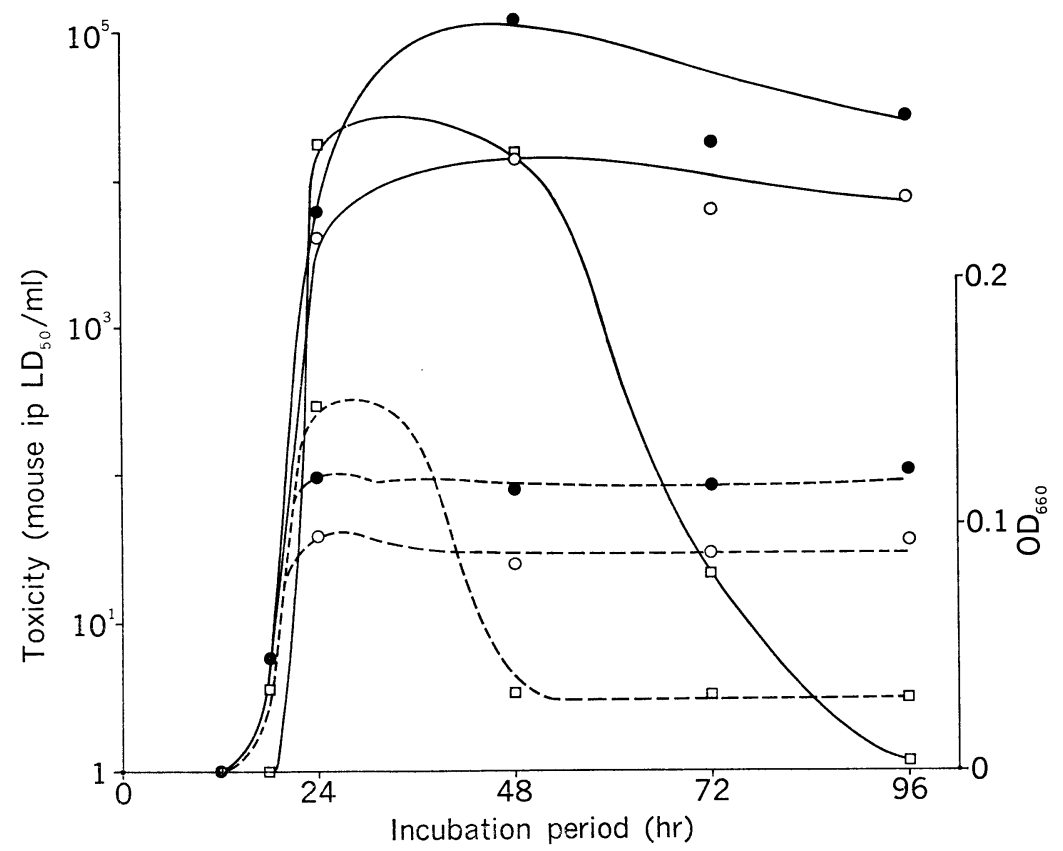

Fig. 4. Growth and toxin production of C. botulinum types A, C, and D at 41 C. Dotted line represents absorbancy at $660 \mathrm{~nm}$ and solid line toxicity in mouse ip $\mathrm{LD}_{50} / \mathrm{ml}$. Symbols: $\square$, type $A$; O, type $C$; $O$, type $D$.

at the same temperature, the rate of inactivation was much more rapid; inactivation of type $A$ toxin was significantly more rapid than that of type $\mathbf{C}$ and $\mathrm{D}$ toxins (Fig. 2, bottom).

Similar experiments were made in $0.01 \mathrm{~m}$ phosphate buffer, $\mathrm{pH} 7.5$. Type A toxin lost about $80 \%$ of the toxicity in $5 \mathrm{hr}$ at $41 \mathrm{C}$, whereas type $\mathrm{G}$ and $\mathrm{D}$ toxins retained nearly $100 \%$ of the toxicity (Fig. 3, top). The destruction curves obtained with the dissociated 7S toxic components of types A and D were nearly the same as those with the corresponding parental 12S toxins (Fig. 3, bottom).

\section{Optimum Temperatures for Growth and Toxin Production by Type $A, C, D$, and $E$ Spores}

In deep $\mathrm{BHI}$ agar culture in the temperature-gradient incubator, development of a visible zone of colonies was most rapid at about 38-40 $\mathrm{C}$ for type $\mathrm{A}$, 40-42 C for types $\mathrm{C}$ and D, and 33-35 C for type E.

In liquid $\mathrm{BHI}$ incubated at $41 \mathrm{C}$, type $\mathrm{E}$ spores failed to grow within $96 \mathrm{hr}$, whereas type A, C, and D spores germinated, grew, and produced toxin. Although type A culture attained higher turbidity than did type $\mathbf{C}$ and $\mathbf{D}$ cultures in $24 \mathrm{hr}$, it produced toxin with titers lower than those in type 
D culture. The highest toxicity of type A culture was $2 \times 10^{4}$ mouse ip $\mathrm{LD}_{50} / \mathrm{ml}$ in $24 \mathrm{hr}$. On the other hand, type $\mathrm{C}$ and $\mathrm{D}$ cultures attained the highest toxin titers of $1 \times 10^{4}$ and $1 \times 10^{5}$ mouse ip $\mathrm{LD}_{50} / \mathrm{ml}$, respectively, in $48 \mathrm{hr}$. The toxicity of type A culture was much lower than its normal level, being over $10^{6} \mathrm{LD}_{50} / \mathrm{ml}$ at $30 \mathrm{C}$, whereas those of type $\mathrm{C}$ and $\mathrm{D}$ cultures were on the same level as those normally attained by incubation at $30 \mathrm{C}$. The toxicity of type A culture decreased rapidly, whereas those of type $\mathrm{C}$ or D culture did not decrease significantly (Fig. 4).

\section{Discussion}

Chickens were most susceptible to type A toxin, about hundredth to thousandth less susceptible to type $\mathrm{B}, \mathrm{C}$, and $\mathrm{E}$ toxins, and still hundredth less susceptible to type $\mathrm{D}$ and $\mathrm{F}$ toxins. The highest susceptibility of chickens to type A toxin has been reported (Gross and Smith, 1971). No chicken was killed by peroral administration of as many as $1 \times 10^{7}$ mouse ip $\mathrm{LD}_{50}$ of type $\mathrm{C}$ toxin free from the C2 factor, although Gross and Smith (1971) reported that $2 \times 10^{5}$ mouse ip $\mathrm{LD}_{50}$ of type $\mathrm{C}$ toxin was lethal to the chicken. Since we found that one chicken iv and intracecal MLD of the C2 factor were only 10 and 100 mouse ip $\mathrm{LD}_{50}$, respectively, we presume that their type $\mathrm{C}$ toxin preparation may have contained some activable C2 factor. Chicken MLD of type E toxin determined by us was about 100 times larger than that determined by Gross and Smith (1971), but it may differ depending upon the strain (Hazen, 1942).

From the peroral lethal doses determined with purified toxins, it may be presumed that preformed botulinum toxin of other than type A (Dickson, 1971; Graham and Schwarze, 1920) can hardly cause botulism in chickens. Further studies are needed to answer the question of whether the preformed C2 factor can cause botulism in chickens.

Considerably large quantities of toxin (10-800 mouse ip MLD/g) were detected in the ceca of all dead cases and smaller amounts of toxin (2-8 MLD/g) in the lower intestines of some chickens administered perorally with spores. All cecoligated chickens but one with insufficient operation survived the feeding of $10^{6}$ spores of type A, C, or D. Intracecum administration required a smaller quantity of toxin than oral or intraduodenal administration to kill the chicken. All these results indicate that the site of production and absorption of botulinum toxin in the chicken body is the cecum. No indication of production of type $\mathrm{C}$ toxin in the crop as reported in phesants (Dinter and Kull, 1954) was obtained.

Type A toxin was 1,000 times more toxic than type $\mathrm{C}$ toxin to the chicken when injected intravenously, but these toxins showed toxicities on a similar level when administered intraduodenally. When the same dose $(0.1 \mathrm{mg})$ of type $\mathrm{A}$ and $\mathbf{C}$ toxins was administered intraduodenally, the blood level of the toxicity of the type $\mathrm{C}$-toxin recipient was 100 times higher than that of the type A-toxin recipient. This was interpreted as indicating that type $\mathrm{A}$ toxin was inactivated more rapidly than type $\mathrm{C}$ toxin in the chicken intestines, as the RPHA test 
detected the same levels of antigenicities of type $\mathrm{A}$ and $\mathrm{C}$ toxins in the blood samples. The toxicity of the cecum contents of type C-spore recipients was higher than that of type A-spore recipients, which was also interpreted as indicating a higher rate of inactivation of type $\mathrm{A}$ toxin in the cecum. These results do not support the hypothesis presented by Gross and Smith (1971) that type $\mathrm{C}$ toxin is absorbed at a higher rate than type $\mathrm{A}$ toxin from the alimentary tract of the chicken.

Type $\mathrm{A}$ toxin was rapidly inactivated but type $\mathrm{C}$ and $\mathrm{D}$ toxins were relatively stable in cecal fluid ( $\mathrm{pH} 7.4$ ) incubated at $41 \mathrm{C}$. In a buffer of $\mathrm{pH} 7.5$, at which $\mathrm{pH}$ botulinum toxin undergoes molecular dissociation into the toxic and nontoxic components, type $\mathrm{A}$ toxin was inactivated rapidly, whereas type C or D toxin was not. The destruction curves obtained with type A and D derivative toxins were the same as those of the respective progenitor toxins under the same conditions, therefore the higher stability under alkaline conditions may be characteristic of type $\mathrm{C}$ and $\mathrm{D}$ derivative toxins. The stability of the C2 factor in the cecum awaits future studies.

The optimum temperature for the growth of $C$. botulinum is generally regarded as 20-37 C, although psychrophilic properties have been found with type $\mathbf{E}$ and nonproteolytic type $\mathbf{B}$ and $\mathbf{F}$ strains (Schmidt, Lechowich and Folinazzo, 1961; Eklund, Poysky and Wieler, 1967; Eklund, Wieler and Poysky, 1967). We found that the optimum temperature for the growth of type $C$ and D organisms is $40-42 \mathrm{C}$, that for type A 38-40 C, and that for type E 33-35 C. At $41 \mathrm{C}$, type $\mathrm{E}$ organisms did not grow or produce toxin, and type A organisms produced toxin but the toxin potency was lower than those produced by type $\mathrm{C}$ and $\mathrm{D}$ organisms. The higher optimum temperature for the growth and the higher stability of the toxin at high $\mathrm{pH}$ values seem to be more favorable for type $\mathrm{C}$ and $\mathrm{D}$ organisms to cause toxico-infection in chickens whose normal body temperature is about $41 \mathrm{C}$.

We can not explain why no case of avian type $\mathrm{D}$ botulism has ever been reported. Our results show that chickens are susceptible to similar extents to toxico-infection by type $\mathrm{C}$ and type $\mathrm{D}$ organisms. Although we proved that chickens are more susceptible to type $\mathrm{C}$ toxin than to type $\mathrm{D}$ toxin, type $\mathrm{D}$ strains are usually better toxin producers. Further studies are needed to clarify if type $\mathbf{C}$ organisms produce larger quantities of the $\mathbf{C} 2$ factor, which was shown to exert higher lethal toxicity to chickens than $\mathrm{Cl}$ or $\mathrm{D}$ toxin, than do type $\mathrm{D}$ organisms in the chicken cecum. Lower density of distribution of type D spores in the environment may be the main reason for the lack of avian cases of type $\mathrm{D}$ botulism.

Recently, cases of infant botulism have been reported in the United States (Arnon et al., 1977). No source of preformed toxin was detected in any case. The cases were diagnosed principally by detecting the toxin and the organisms in feces. In such infant botulism cases, toxico-infection has also been suggested (Arnon et al., 1977). It should be interesting to find if the site of toxin production and absorption in human toxico-infection is the cecum or appendix and if 
appendectomy or cecectomy could prevent infants from toxico-infection with C. botulinum.

\section{REFERENCES}

Arnon, S. S., Midura, T. F., Clay, S. A., Wood, R. M. And Chin, J. (1977): Infant botulism: Epidemiological, clinical, and laboratory aspects. Am. J. Med. Assoc., 237, 1946-1951.

Blandford, T. B. AND Roberts, T. A. (1970): An outbreak of botulism in broiler chickens. Vet. Rec., 87, 258-261.

Boroff, D. A. AND Fleck, U. (1966): Statistical analysis of a rapid in vivo method for the titration of the toxin of Clostridium botulinum. J. Bacteriol., 92, 1580-1581.

Bruch, M. K., Bohrer, C. W. ANd Denny, C. B. (1968): Adaptation of biphasic culture technique to the sporulation of Clostridium botulinum type E. J. Food Sci., 33, 108-109.

DAck, G. M. AND GibBard, J. (1926): Studies on botulinum toxin in the alimentary tract of hogs, rabbits, guinea-pigs and mice. J. Infect. Dis., 39, 173-180.

DAck, G. M. AND Hoskins, D. (1942): Absorption of botulinum toxin from the colon of Macaca mulatta. J. Infect. Dis., 71, 260-263.

DAck, G. M. AND Wood, W. L. (1927): Impermeability of the small intestine of rabbits to botulinum toxin. J. Infect. Dis., 40, 585-587.

Dickson, E. C. (1917): Botulism: A cause of limber-neck in chickens. J. Am. Vet. Med. Assoc., $50,612-613$.

Dinter, Z. AND Kull, K. E. (1954): Über einen Ausbruch des Botulismus bei Fasanenküken. Nord. Vet. Med., 6, 866-872.

Eklund, M. W. AND Poysky, F. T. (1972): Activation of a toxic component of Clostridium botulinum type C and D by trypsin. Appl. Microbiol., 24, 108-113.

Eklund, M. W., Poysky, F. T. ANd Wieler, D. I. (1967): Characteristics of Clostridium botulinum type F isolated from the Pacific coast of the United States. Appl. Microbiol., 15, 1316-1323.

Eklund, M. W., Wieler, D. I. ANd Poysky, F. T. (1967): Outgrowth and toxin production of nonproteolytic type B Clostridium botulinum at 3.3 to 5.6 C. J. Bacteriol., 93, 1461-1462.

Graham, R. AND Scharze, H. (1920): Avian botulism (type A) or limber neck. J. Infect. Dis., $28,317-322$.

Greenberg, R. A., Bladel, B. O. and Zingelmann, W. J. (1966): Use of the anaerobic pouch in isolating Clostridium botulinum spores from fresh meats. Appl. Microbiol., 14, 223-228.

Gross, W. B. AND SMith, L. DS. (1971): Experimental botulism in gallinaceous birds. Avian Dis., $15,716-722$.

HaAgsma, J. (1974): An outbreak of botulism in broiler chickens. Tijdschr. Diergeneesk., 99, 979-980.

HAzEN, E. L. (1942): Differential characteristics of two strains of Clostridium botulinum type E: Activation of toxin in chickens. Proc. Soc. Exp. Biol. Med., 50, 112-114.

Itoh, T., SAKaI, S., TABuchi, K., ImaI, N. AND EkI, T. (1976): An outbreak of botulism on a mink farm in Hokkaido. Bull. Azabu Vet. Coll., 1, 29-35 (text in Japanese).

Jansen, B. C. (1971): The toxic antigenic factors produced by Clostridium botulinum types C and D. Onderstepoort J. Vet. Res., 38, 93-98.

Jansen, B. C. And Knoetze, O. C. (1971): Tryptic activation of Clostridium botulinum type C $\beta$ toxin. Onderstepoort J. Vet. Res., 38, 237-238.

Kitamura, M., Sakaguchi, S. And Sakaguchi, G. (1968): Purification and some properties of Clostridium botulinum type-E toxin. Biochim. Biophys. Acta, 168, 207-217.

Kitamura, M., Sakaguchi, S. And Sakaguchi, G. (1969): Significance of 12S toxin of Clostridium botulinum type E toxin. J. Bacteriol., 98, 1173-1178.

Kozakr, S., Sakaguchi, S. And Sakaguchi, G. (1974): The purification and some properties of progenitor toxins of Clostridium botulinum type B. Infect. Immun., 10, 750-756.

Lowry, D. H., Rosebrough, N. J., Farr, A. L. And Randall, R. J. (1951): Protein measurement with the Folin phenol reagent. J. Biol. Chem., 193, 265-275.

May, A. J. ANd Whaler, B. C. (1958): The absorption of Clostridium botulinum type A toxin from the alimentary canal. Brit. J. Exptl. Pathol., 39, 307-316.

Miyazaki, S., Iwasaki, M. AND Sakaguchi, G. (1977): Clostridium botulinum type D toxin: 
Purification, molecular construction, and some immunological properties. Infect. Immun., 17, 395-401.

Moore, W. B. (1968): Solidified media suitable for the cultivation of Clostridium novyi type B. J. Gen. Microbiol., 53, 415-423.

Oguma, K., IIDA, H. AND INOUE, K. (1973): Bacteriophage and toxigenicity in Clostridium botulinum: An additional evidence for phage conversion. Japan. J. Microbiol., 17, 425-426.

Ohishi, I. AND SAKaguchi, G. (1974): Purification of Clostridium botulinum type F progenitor toxin. Appl. Microbiol., 28, 923-928.

Page, R. K. And Flettcher, O. J. (1974): Case report: An outbreak of type-C botulism in threeweek-old broilers. Avian Dis., 19, 192-195.

Roberts, T. A. And Collings, D. F. (1973): An outbreak of type-C botulism in broiler chicken. Avian Dis., 17, 650-658.

Roberts, T. A., Thomas, A. I. And Gilbert, R. J. (1973): A third outbreak of butulism in broiler chickens. Vet. Rec., 92, 107-109.

Sakaguchi, G., SaKaguchi, S., Kozaki, S., Sugir, S. ANd Ohishi, I. (1974): Cross reaction in reversed passive hemagglutination between Clostridium botulinum type A and B toxins and its avoidance by the use of anti-toxic component immunoglobulin isolated by affinity chromatography. Japan. J. Med. Sci. Biol., 27, 161-172.

SchmidT, C. R. AND NANK, W. K. (1960): Radiation sterilization of food. I. Procedures for the evaluation of the radiation resistance of spores of Clostridium botulinum in food products. Food Res., 25, 321-327.

Schmidt, C. F., Lechowich, R. V. And Folinazzo, J. F. (1961): Growth and toxin production by type E Clostridium botulinum below $40^{\circ}$ F. J. Food Sci., 26, 626-630.

Segner, W. P., Schmidt, C. F. ANd Boltz, J. K. (1971): Enrichment, isolation, and cultural characteristics of marine strains of Clostridium botulinum type C. Appl. Microbiol., 22, $1017-1024$.

Smart, J. L. ANd Roberts, T. A. (1977): An outbreak of type C botulinum in broiler chickens. Vet. Rec., 100, 378-380.

Sugir, S. AND SAKAGUCHI, G. (1975): Molecular construction of Clostridium botulinum type A toxins. Infect. Immun., 12, 1262-1270.

Sugir, S., Ohishi, I. AND SAKaguchi, G. (1977): Intestinal absorption of botulinum toxins of different molecular sizes in rats. Infect. Immun., 17, 491-496. 